\title{
Open geospatial data, software and standards
}

Mohamed Bakillah ${ }^{1^{*}}$ and Steve Liang ${ }^{2}$

The "open" movement, which promotes the use of open source licenses for data and software, started in fact in the early days of computing, when groups of scientists were sharing computers while developers were working on common source code [1]. While this movement, since then, has not always been popular, today, it has resulted in major initiatives, including The GNU Project and its licenses, [2], this not-for-profit organization created to raise awareness on and advocate for open source (OSI n.d.), and the Open Data Commons, which provides licenses under which popular projects like OpenStreetMap (OSM) operate.

Today, governments from around the world and stakeholders from the business sector both participate to and promote open geospatial data, software and standards initiatives. Governments increasingly provide free access to various types of geospatial data, typically statistical data, land use and land cover data, topographic data, among others, as they realize its potential to foster economic, social and environmental opportunities. Furthermore, open standards like those of the Open Geospatial Consortium (OGC) are at the core of major infrastructures such as the European Union's INSPIRE Spatial Data Infrastructure (SDI).

The spectrum of projects and activities that employ open geospatial data, software and standard is huge: from implementation of open standards for Sensor Web Enablement (SWE) like the GeoCENS and 52 North platforms, which enable the sharing of sensor data, to the thousands of research projects and applications based on OSM, possibilities seem unlimited.

Concrete projects based on open geospatial data are now having significant and measurable impact on communities, economy, political life, environment, health, transportation, only to name a few areas. These concrete projects range from sharing data on police actions and

\footnotetext{
* Correspondence: mohamed.bakillah@geog.uni-heidelberg.de

'University of Heidelberg, Heidelberg, Germany

Full list of author information is available at the end of the article
}

engagement in communities to reinforce trust in and transparency of law enforcement bodies, mapping pollen activity based on open data collected through Internetof-Things (IoT) infrastructures, and enabling health scientists to share information with the public on clinical studies. While such initiatives have benefits on their own, the data they generate can be reused for a variety of purposes that differ from that initially planned, which constitutes the real potential of open geospatial data, software and standards.

Still, while today the focus is on making data open through SDI, open data catalogs, or also through crowdsourcing platforms, like the popular OSM, the processing of the data and combination of data and software remain limited [3]. Obstacles are multiple and include, for example, limited interoperability at the semantic level, size of data sets, discovering capacities, and adapting open data mash-ups so they address the specificities of geospatial data. Therefore, research in these areas will remain of high relevance to the success of the open paradigm.

Journal of Open Geospatial Data, Software and Standards was created to address this need. More specifically, its aim is to provide an advanced forum for the science and technology of open data, crowdsourced information, and sensor web through the publication of reviews and regular research papers. The journal publishes papers that address issues related, but not limited to, the analysis and processing of open geo-data, standardization and interoperability of open geo-data and services, open software as well as applications based on open geo-data. The journal is also meant to be a space for theories, methods and applications related to crowdsourcing, volunteered geographic information, as well as Sensor Web and related topics.

The journal aims to publish papers that address a large variety of questions related to open data software and standards, such as how to support the

\section{Springer}


availability of up-to-date, reliable, and interoperable open geospatial data, and which mechanisms can be put in place to promote innovation based on open geospatial data, software and standard, and effective cooperation and exchange between stakeholders. We look forward to receiving high-quality contributions that relate this research area.

\section{Author details}

${ }^{1}$ University of Heidelberg, Heidelberg, Germany. ${ }^{2}$ University of Calgary,

Calgary, Canada.

Published online: 03 March 2016

\section{References}

1. Herold, NA 2015. Topographic Maps from Open Data. TUWien, Austria: Universität Wien http://othes.univie.ac.at/36179/1/2015-02-04_0326453.pdf

2. The Open Source Initiative (OSI). N.d. "Welcome to The Open Source Initiative." http://opensource.org/. Accessed 23 October 2015.

3. Rojas, G, Giannopoulos, G, and Hladky, JJLD 2015. "Managing Geospatial Linked Data in the GeoKnow Project." T. Narock and P. Fox (eds.). The Semantic Web in Earth and Space Science. Current Status and Future Directions, 20, 51.

\section{Submit your manuscript to a SpringerOpen ${ }^{\mathcal{O}}$ journal and benefit from:}

- Convenient online submission

- Rigorous peer review

- Immediate publication on acceptance

- Open access: articles freely available online

- High visibility within the field

- Retaining the copyright to your article

Submit your next manuscript at $\gg$ springeropen.com 